\title{
Fracture Sealing with Microbially-Induced Calcium Carbonate Precipitation: A Field Study
}

\section{Authors: Adrienne J. Phillips, Alfred B. Cunningham, Robin Gerlach, Randy Hiebert, Chiachi Hwang, Bartholomeus P. Lomans, Joseph Westrich, Cesar Mantilla, Jim Kirksey, Richard Esposito, \& Lee Spangler}

NOTICE: This document is the unedited author's version of a Submitted Work that was subsequently accepted for publication in Bioscience, copyright (C American Chemical Society after peer review. To access the final edited and published work, see http://dx.doi.org/10.1021/ acs.est.5b05559."

Phillips AJ, Cunningham AB, Gerlach R, Hiebert R, Hwang C, Lomans BP, Westrich J, Mantilla C, Kirksey J, Esposito R, Spangler L, "Fracture Sealing with Microbially-Induced Calcium Carbonate Precipitation: A Field Study," Environmental Science and Technology 2016 50(7) pp. $4111-4117$ 


\title{
Fracture Sealing with Microbially-Induced Calcium Carbonate Precipitation: A Field Study
}

\author{
Adrienne J. Phillips, ${ }^{*}{ }^{\dagger}$ Alfred B. Cunningham, ${ }^{\dagger}$ Robin Gerlach, ${ }^{\dagger}$ Randy Hiebert, ${ }^{\dagger}$ Chiachi \\ Hwang, ${ }^{\dagger}$ Bartholomeus P. Lomans, ${ }^{\S}$ Joseph Westrich, ${ }^{\perp}$ Cesar Mantilla, ${ }^{\perp}$ Jim Kirksey, $\|, \nabla$ \\ Richard Esposito, \\ and Lee Spangler ${ }^{\otimes}$
${ }^{\dagger}$ Center for Biofilm Engineering, Montana State University, RM 366 EPS Building, Bozeman, Montana 59717, United States
${ }^{\ddagger}$ Montana Emergent Technologies, 160 W. Granite Street, Butte, Montana 59701, United States
Shell Global Solution International B.V., Kessler Park 1, 2288 GS Rijswijk, The Netherlands
${ }^{\perp}$ Shell International Exploration and Production Inc. 3333 Highway 6 South, Houston, Texas 77025, United States
"Loudon Technical Services LLC, 1611 Loudon Heights Road, Charleston, West Virginia 25314, United States
Southern Company, P.O. Box 2641, BIN 14N-8195, Birmingham, Alabama 35291-8195, United States
${ }^{\otimes}$ Energy Research Institute, Montana State University, P.O. Box 172465, Bozeman, Montana 59717, United States

\begin{abstract}
A primary environmental risk from unconventional oil and gas development or carbon sequestration is subsurface fluid leakage in the near wellbore environment. A potential solution to remediate leakage pathways is to promote microbially induced calcium carbonate precipitation (MICP) to plug fractures and reduce permeability in porous materials. The advantage of microbially induced calcium carbonate precipitation (MICP) over cement-based sealants is that the solutions used to promote MICP are aqueous. MICP solutions have low viscosities compared to cement, facilitating fluid transport into the formation. In this study, MICP was promoted in a fractured sandstone layer within the Fayette Sandstone Formation $340.8 \mathrm{~m}$ below ground surface using conventional oil field subsurface fluid delivery technologies (packer and bailer). After 24 urea/calcium solution and 6 microbial (Sporosarcina pasteurii) suspension injections, the injectivity was decreased (flow rate decreased from 1.9
\end{abstract}

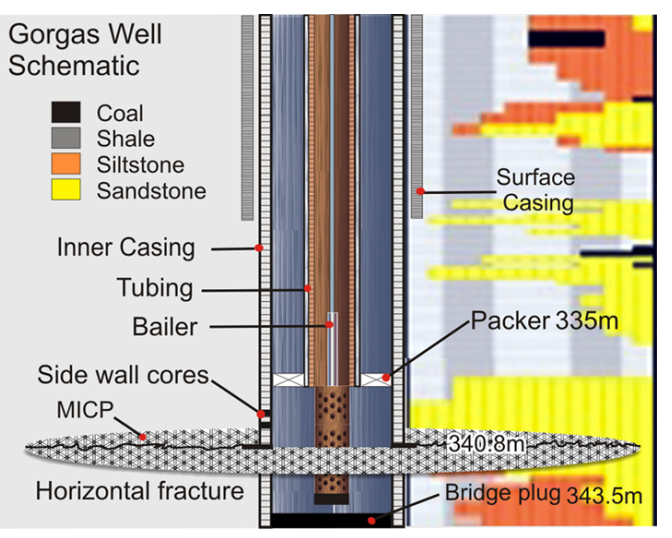

to $0.47 \mathrm{~L} / \mathrm{min}$ ) and a reduction in the in-well pressure falloff ( $>30 \%$ before and $7 \%$ after treatment) was observed. In addition, during refracturing an increase in the fracture extension pressure was measured as compared to before MICP treatment. This study suggests MICP is a promising tool for sealing subsurface fractures in the near wellbore environment.

\section{INTRODUCTION}

A primary environmental risk from unconventional oil and gas development or carbon sequestration is subsurface fluid leakage. 1,2 The leakage may occur through diffusion of the fluid through the caprock or through high permeability regions in the near wellbore environment, caused for example through a fracture or debonding of cement around the casing. 3,4 Leakage may contribute risk to human or environmental health by damage to functional aquifers or emission to the surface. The leakage might contribute to increased greenhouse gas (GHG) emissions, not only from leaked $\mathrm{CO}_{2}$ but also natyral gas (methane) that is a potent GHG. ${ }^{2}$.n addition, methane leakage to the surface could contribute to the formation of ozone, a regulated air pollutant. 5 One method to seal fractures to improve caprock or wellbore integrity is the use of microbially induced calcium carbonate precipitation (MICP). This technology has the potential to seal subsurface fractures, thus improving environmental safety for oil and gas development and carbon sequestration activities.
Biomineralization. Microbes can alter the chemistry of their surrounding environments, which in some cases can result in supersaturation and precipitation of minerals such as calcium carbonate. ${ }^{6}$ Certain microorganisms attached to surfaces (biofilms) produce the enzyme urease that can catalyze the hydrolysis of urea to produce ammonium and carbonate species. In the presence of calcium, this reaction can create conditions favorable for precipitation of calcium carbonate $\left(\mathrm{CaCO}_{3}\right)$. In MICP, the urea hydrolysis influences chemical conditions (saturation state) through increasing the dissolved inorganic carbon (DIC) concentration and increasing the $\mathrm{pH}$ value, effectively increasing the carbonate alkalinity. ${ }^{7,8}$ The resulting precipitation of $\mathrm{CaCO}_{3}$ depends on the saturation 
state of the mineral and the presence of nucleation sites as described in detail elsewhere. ${ }^{6}$

Biotechnology Application. MICP has been investigated for a wide range of engineering applications ${ }^{6}$ including amending or improving construction materials, ${ }^{9,10}$ cementing porous media, ${ }^{11-13}$ and environmental remediation. ${ }^{14}$ In the subsurface, MICP has the potential to be a tool to reduce subsurface leakage of geologically sequestered carbon dioxide, ${ }^{8,15,16}$ methane, ${ }^{17}$ and improve the containment of nuclear waste. ${ }^{18}$ MICP can deposit calcite in preferential flow paths in porous media and in the near-wellbore environment to mitigate leakage potential. ${ }^{15}$ The primary advantage of the MICP technology is that relatively low viscosity aqueous solutions are used to promote precipitation to seal unwanted flow paths especially in small aperture fractures. The advantage of low viscosity fluids is also that they may be pumped further into the formation compared to higher viscosity fluids, such as cements, which may impact permeability only near the injection point.

Field Deployment. Although successful MICP fracture sealing demonstrations have been performed in the laboratory, ${ }^{15,19}$ field deployment is necessary to advance commercialization of the technology. To date, only a few MICP-related field studies have been reported. These studies include the use of MICP to promote urea hydrolysis and calcite precipitation in groundwater, ${ }^{14}$ strengthen liquefiable soils, ${ }^{20}$ and promote fracture sealing $25 \mathrm{~m}$ below ground surface in the volcanic rock, dacite. ${ }^{18}$ The study presented herein adds to previous demonstrations and laboratory experiments by demonstrating the use of MICP in fractured sandstone $340.8 \mathrm{~m}$ below ground surface using conventional oil field delivery techniques.

In specific, this paper provides details about a field demonstration of MICP for fracture sealing performed at the William Crawford Gorgas Electric Generating Plant (Alabama Power, Southern Company) near Jasper, Alabama (hereafter referred to as "Gorgas"). The objectives of the experiment were to (1) develop methods for delivering MICP promoting fluids downhole using conventional oil field technologies and (2) assess the ability of MICP to seal a subsurface horizontally fractured sandstone formation in the near wellbore region. The objectives were met through bioaugmentation with Sporosarcina pasteurii combined with urea and calcium injections over the course of 4 days. Conventional oil field methods were used to deliver the biomineralization solutions and bacterial suspensions downhole by using an $11.4 \mathrm{~L}$ wireline dump bailer combined with periodic pumping of a brine solution into the fractured formation. Sealing of the fracture with MICP was assessed through (i) the reduction of injectivity during seal formation, (ii) decrease in pressure decay after well shut in, (iii) recovery of $S$. pasteurii from subsurface fluid samples, and (iv) demonstration of MICP byproducts including calcium carbonate $\left(\mathrm{CaCO}_{3}\right)$ in side wall cores retrieved from the treated regions. The field demonstration occurred in the following sequence: (1) field site characterization (2) fracturing the sandstone formation to develop injectivity, (3) injection of microbial and calcium solutions in the field using conventional oil field delivery technologies, and (4) assessment of the fracture plugging and refracturing resistance after treatment.

\section{MATERIALS AND METHODS}

Field Site Description. Collaborators from Southern Company, Schlumberger, Shell, Montana Emergent Technologies, and Montana State University mobilized to the Gorgas Power Plant to initiate an ureolysis-driven MICP field demonstration. The Gorgas \#1 well, located at the plant site, had been a stratigraphic test well drilled in the fall of 2011. The drilling effort was performed as part of a U.S. Department of Energy (DOE) effort to characterize the geologic formations to assess carbon dioxide sequestration opportunities in deep saline reservoirs. The Gorgas \#1 well, drilled to $1498 \mathrm{~m}$ is cased with a $24.4 \mathrm{~cm}$ casing. On the basis of a review of the petrophysical analysis (well $\log$ ) prepared by Schlumberger Carbon Services, multiple layers of shale, sandstone, and coal were assessed as possible field test formation candidates. The Fayette sandstone group at a depth of 338.3 to $341.4 \mathrm{~m}$ was chosen for performing the field demonstration (Figure 1) because it

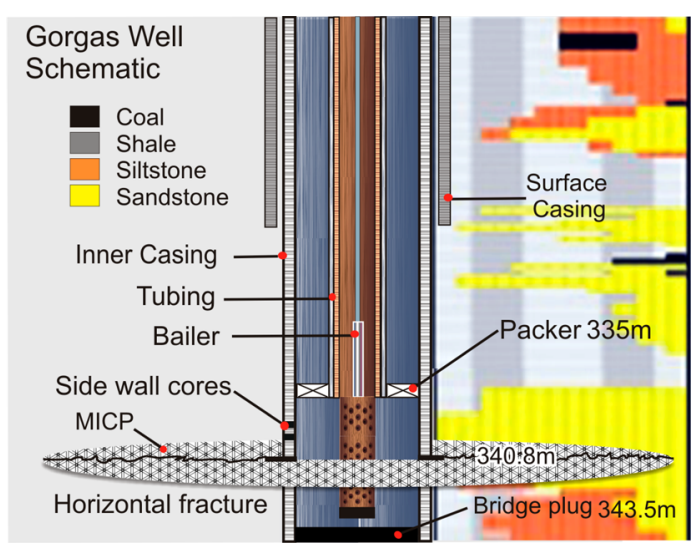

Figure 1. Configuration of the Gorgas \#1 well with stratigraphic information on the right-hand side (sandstone (yellow), shale (gray), coal (black)) and the subsurface fluid delivery and injection system. A bailer on a wireline was used to deliver concentrated solutions and bacterial suspensions to the region of the fracture that was formed at $340.8 \mathrm{~m}$ below the ground surface (bgs) in the Fayette sandstone formation. A bridge plug was set at $343.5 \mathrm{~m}$ bgs and the packer attached to a $7.3 \mathrm{~cm}$ tubing string was set at $335 \mathrm{~m}$ bgs. The tubing string ran to the surface and was used to deliver brine to dilute concentrated bailer contents and deliver them into the fracture. MICP is indicated with a black and white hatch pattern in the estimated horizontal fracture that formed.

provided sufficient permeability to inject fluids, a necessary prerequisite for sealing technologies such as MICP. The Fayette sand in this zone was a medium to fine-grained sandstone with a porosity of approximately $10 \%$ and a permeability of approximately $3 \mathrm{mD}$ (personal communications, Richard Esposito, Southern Company and Jim Kirksey, Schlumberger Carbon Services). The cement bond log (not shown) indicated good cement across the zone, so hydraulic isolation was expected.

The well was cased completely to the bottom, so the casing in the target region was perforated in order to access the formation. Perforation of the casing and the formation occurred with six shots at 60 degree phasing within the zone from 340.7 to $341.1 \mathrm{~m}$ bgs. The perforations were estimated to have a 0.89 $\mathrm{cm}$ entry hole and extend $50.8 \mathrm{~cm}$ into the formation. After perforation and sump amendment (see Supporting Information (SI) for details), the packer was engaged to isolate the Fayette Formation. The tubing string was equipped with downhole pressure memory gauges (Schlumberger, USA) below the packer. A collar stop was placed between two $1.2 \mathrm{~m}$ perforated pipes on which the bailer could land and open (Figure 1). The tubing was set into the well with the end of the perforated tubing at $341.7 \mathrm{~m}$. Black Warrior River water was trucked from 
the plant to two $2082 \mathrm{~L}$ holding tanks where it was amended with $\mathrm{NaCl}$ (Mix-N-Fine, Cargill, Minnesota, USA) to $2.4 \%$ final $\mathrm{NaCl}$ concentration (hereafter referred to as the brine). The flow rate from the Cat Model 310 (Cat Pumps, Minneapolis, $\mathrm{MN}$ ) injection pump powered by a $5 \mathrm{HP} 230 \mathrm{~V}$ motor with a variable speed drive was monitored by a Hoffer flow meter (Hoffer Inc., North Carolina, USA) with an Omega (Omega Engineering Inc., Connecticut, USA) pressure data logger to record surface pressure. The injection pump was connected to the tubing string to be able to pump brine into the subsurface.

To create injectivity into the formation, the formation was stimulated by increasing the brine injection flow rate until a downhole pressure of $105.9 \mathrm{~atm}$, when the formation's fracture initiation pressure was reached. An injection test was performed by pumping brine at $1.9 \mathrm{~L} / \mathrm{min}$ for $6 \mathrm{~h}$, which resulted in a steady downhole pressure of $68 \mathrm{~atm}$. The target flow rate of 1.9 $\mathrm{L} / \mathrm{min}$ was chosen for the biomineralization study to remain below fracture initiation pressure during the MICP treatment period. After the $6 \mathrm{~h}$ injection test, the well was shut in for an $88 \mathrm{~h}$ pressure falloff test. From the pressure falloff data, it was estimated that a horizontal radial fracture was created.

Field Test Design. The MICP field test occurred over 4 days using a pulsed injection strategy similar to the one described in $^{21}$ with delivery of concentrated solutions via a slickline dump bailer. The bailer is a hollow tube with a valve on the bottom, which was filled with different fluid mixtures and then sent downhole where it sat down on the collar stop causing a pin to shear and the bottom bailer valve to open. There were two types of fluid mixtures delivered with the bailer: (1) inoculum: Sporosarcina pasteurii, ATCC 11859, formerly Bacillus pasteurii ${ }^{22}$ culture prepared as described in Table S1 amended with $24 \mathrm{~g} / \mathrm{L}$ urea fertilizer (Potash Corporation, Illinois, USA) and $3 \mathrm{~g} / \mathrm{L}$ Nutrient Broth (Research Products International, Illinois, USA) and (2) calcium containing growth solution: $99 \mathrm{~g} / \mathrm{L} \mathrm{CaCl}_{2}$ (Oxy Chem Ice Melt, Michigan, USA), $23.3 \mathrm{~g} / \mathrm{L} \mathrm{NH}_{4} \mathrm{Cl}$ (BASF, New Jersey, USA), $56 \mathrm{~g} / \mathrm{L}$ urea, and $7.0 \mathrm{~g} / \mathrm{L}$ (Becton Dickinson Nutrient Broth, New Jersey, USA) mixed with brine. The cell concentration in the inoculum was assessed using colony forming unit (cfu) counts on brain heart infusion (BHI) + urea agar plates via the drop plate method ${ }^{23}(37 \mathrm{~g} / \mathrm{L}$ BHI, Becton Dickinson, New Jersey, USA), $20 \mathrm{~g} / \mathrm{L}$ urea (Fisher Scientific, New Jersey, USA), 15 g/L Difco agar (Becton Dickinson, New Jersey, USA (Table S2)). The inoculum was amended with urea and nutrient broth to promote growth after injection. The concentrations of the calcium containing growth solutions were chosen such that the dilution with brine would yield substrate concentrations in the fracture supportive of MICP, (the targeted concentrations were: $24 \mathrm{~g} / \mathrm{L}$ urea, $10 \mathrm{~g} / \mathrm{L} \mathrm{NH}_{4} \mathrm{Cl}, 3$ $\mathrm{g} / \mathrm{L}$ Nutrient Broth, and $39 \mathrm{~g} / \mathrm{L}$ calcium chloride). ${ }^{17}$ The actual concentration achieved in the fracture after dilution was based on the amount of brine pumped, which averaged $28.7 \pm 7 \mathrm{~L}$ after each bailer delivery (Table S3). The inoculum and calcium containing growth solution were injected separately with a brine rinse between injections in order to minimize direct contact between inoculum and calcium containing solutions potentially resulting in undesirable MICP within the $7.3 \mathrm{~cm}$ diameter tubing or the wellbore mixing zone.

The use of the $9.1 \mathrm{~m}$ long $5.1 \mathrm{~cm}$ diameter, $11.4 \mathrm{~L}$, slickline dump bailer was chosen as the most economical conventional oil and gas field methodology to deliver the substrates to the subsurface. Substrates or microbial suspensions (inoculum) were mixed in a tank at the ground surface and the bailer was filled by pumping the solutions into the top of the bailer. The filled bailer was lowered into the well into the region of the fracture where it was opened to release the inoculum. The inoculum was delivered into the fracture and formation by pumping brine through the tubing string. S. pasteurii cells were allowed to attach to the formation for $1 \mathrm{~h}$ after injection prior to bailer deliveries of concentrated calcium growth solutions each followed by brine dilution. Prior to an overnight shut in period, a second microbial inoculum was delivered at $3.7 \mathrm{~h}$ after the initial inoculation (Table S3). Pressure and flow rate during injection and pressure falloff in between flowing periods were monitored and recorded by the surface and subsurface pressure gauges. The bailer was rinsed with brine between calcium containing solutions and microbial suspensions and at the end of each day. Each day, the well was shut in overnight. Injections occurred for 4 days, as detailed in Table S3.

Sampling and Chemical Analysis. Prior to the initial inoculation (which defines the time zero of the experiment, Table S3), fluids in the well casing at 340 to $341 \mathrm{~m}$ bgs were sampled using the Wireline Kuster Sampling tool (Schlumberger, Florida, USA). The Kuster sampler was set on a timer to open after placement into the wellbore mixing zone and close after $20 \mathrm{~min}$. Once closed, the tool was retrieved and the wellbore liquid sample was collected in an autoclaved bottle (Nalgene, Thermo Fisher Scientific New York, USA). Additional samples were collected at 18.3 and $52.1 \mathrm{~h}$ after the initial inoculation (Table S3). The sample collected at $52.1 \mathrm{~h}$ was collected after injection of the inoculum and a pull-back of fluids from the fracture into the mixing zone of the isolated well casing. Portions of the sample were used to assess the microbial community, concentration of urea and calcium, as well as $\mathrm{pH}$ (Table S4). Concentration of urea was assessed by a modified method of the Jung Assay. ${ }^{24,25}$ The $\mathrm{pH}$ was assessed with a two-point calibrated meter (Accumet AP71, Fisher Scientific, New Jersey, USA). Calcium concentrations were assessed using ion chromatography (IC) at Montana State University (MSU) as previously described (Table S4). ${ }^{15,21}$ The formation water was also chemically analyzed (Table S5).

Unfiltered samples from each mixing zone sample were plated onto BHI + urea agar to assess culturability of microorganisms. Unique colonies that grew on the $\mathrm{BHI}+$ urea agar plates were streaked for isolation on fresh agar plates at MSU, after which they were inoculated into autoclaved BHI + urea liquid medium and cultured at room temperature. Identification of the isolates via $16 \mathrm{~S}$ rRNA gene sequencing was then performed (SI). A portion of the sample $(350 \mathrm{~mL})$ was filtered through a $0.2 \mu \mathrm{m}$ bottle top filter (Thermo Scientific, New York, USA). The filter portion was aseptically cut from the filter top and transferred to a sterile $50 \mathrm{~mL}$ centrifuge tube that was placed on dry ice and shipped to MSU. These filtered samples were placed into a $-80{ }^{\circ} \mathrm{C}$ freezer for storage until bacterial community analysis commenced (SI).

Experiment Termination and Postexperiment Analysis. The experiment was terminated when fluids could no longer be injected through the tubing without exceeding the threshold pressure (TP). The TP was set at $81.6 \mathrm{~atm}$ to remain well below the initially observed fracture extension pressure (96.6 atm). Over the course of the experiment, the flow rate was reduced from the original $1.9 \mathrm{~L} / \mathrm{min}$ to prevent the pressure from increasing above the fracturing pressure during the treatment period. The pressure decay was monitored by recording the decrease in well pressure for $5 \mathrm{~min}$ after shut in (pumping stopped), a $100 \%$ reduction would be equivalent to 
the well head pressure decreasing to atmospheric pressure indicating, for example, leakage or unobstructed flow into a formation. At the end of the experiment, a step rate test was performed where pumping pressures were increased until the formation refractured.

One year after the MICP sealing experiment, Schlumberger retrieved samples from the region of the fracture by drilling side wall cores at 337.7 and $338.9 \mathrm{~m}$ below ground surface. A cement plug and piece of the casing was retrieved from the $338.9 \mathrm{~m}$ location and the cement portion was imaged using Xray Micro Computed Tomography (Micro-CT) (Sky Scan 1173, Bruker USA, Wisconsin, $100 \mathrm{kV}$, no filter). The cement core was also analyzed with a Leica M205FA stereomicroscope using reflected white light and fluorescence, (DAPI cube, ex 350/50, em 460/50, Leica Microsystems, Illinois). Drilling mud type material was retrieved from the $337.7 \mathrm{~m}$ location, which was dried in a sterile Petri dish on the benchtop in the laboratory prior to being analyzed using X-ray powder diffraction spectrometry (XRD) (Scintag X-GEN 4000 XRD) at MSU's Image and Chemical Analysis Laboratory (SI).

\section{RESULTS AND DISCUSSION}

Analysis of MICP Fracture Seal. The injection strategy developed for this field demonstration utilized conventional oil field technology to deliver successfully MICP promoting materials into the subsurface. This experiment demonstrated the application of a pulsed injection strategy (detailed in Table S3) developed by us previously ${ }^{21}$ to deliver microbes and separately inject calcium growth solutions using the bailer followed by brine flow to deliver microbes and/or substrates into the formation. This strategy was modeled after similar laboratory experiments that had been shown to reduce near injection point plugging by rinsing the near injection point with a solution that did not contain calcium. ${ }^{21}$ In the case of the field experiment, the rinse solution was the brine pumped down the tubing string after the bailer delivery. The injection strategy developed to treat the fracture altered the flow characteristics into the formation: reduced injectivity, a reduction in pressure decay after well shut in, and an increase in the fracture extension pressure was achieved after MICP treatment.

Reduced Injectivity. Twenty four (24) calcium pulses and 6 microbial cultures were delivered into the perforated zone over the course of 4 days. After calcium pulse \#22 (hour 69 after the first inoculation), fluids could not be pumped at the original flow rate $(1.9 \mathrm{~L} / \mathrm{min})$ without exceeding the threshold pressure (81.6 atm) (Figure 2).

The initial flow rate was $1.9 \mathrm{~L} / \mathrm{min}$, which was decreased to as low as $0.47 \mathrm{~L} / \mathrm{min}$ to remain below the TP as MICP treatment progressed. The original pressure increased from approximately $69.4 \mathrm{~atm}$ to as high as 81.6 atm over the course of the treatment. On the basis of the calcite retrieved from the subsurface mud samples (SI) and observations of significant mineral forming in fractures from previous laboratory experiments, ${ }^{15,19}$ the reduction of injectivity was attributed to MICP. Calcium carbonate precipitates are postulated to have filled void spaces and blocked flow pathways in the near wellbore environment. Because this field demonstration had to be performed without a parallel control experiment, it cannot be ruled out that the injectivity was also reduced due to the accumulation of biofilms capable of reducing permeability in porous media. Previous studies in the laboratory have shown no permeability reduction occurred without the addition of

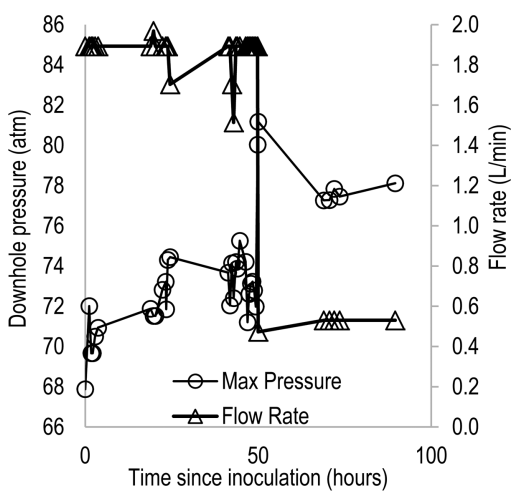

Figure 2. Pressure $(O)$ and flow rate $(\Delta)$ relationship over the course of the MICP experiment. As the pressure increased, the flow rate was decreased over the course of the experiment.

bacteria when similar urea and calcium containing solutions were injected. $^{26-28}$

Pressure Falloff. For injection wells, Title 40 of the Code of Federal Regulations Section 146.8 defines mechanical integrity (MI) as having no significant leak in the casing, tubing, or packer that can be measured with an annulus pressure test. ${ }^{29,30}$ In this experiment, the well was pressurized with liquid during every injection and pressure decay was monitored after well shut in (pumping stopped and the valve was closed on the wellhead). The pressure decay continued to improve (less pressure decay over time) over the course of the experiment and ended with a promising $7 \%$ pressure falloff over $5 \mathrm{~min}$, i.e., significantly reduced from greater than $30 \%$ pressure falloff over $5 \mathrm{~min}$ prior to the MICP treatment (Figure 3). The positive result observed in the reduction of pressure decay suggested that wellbore integrity might be improved by treatment with MICP.

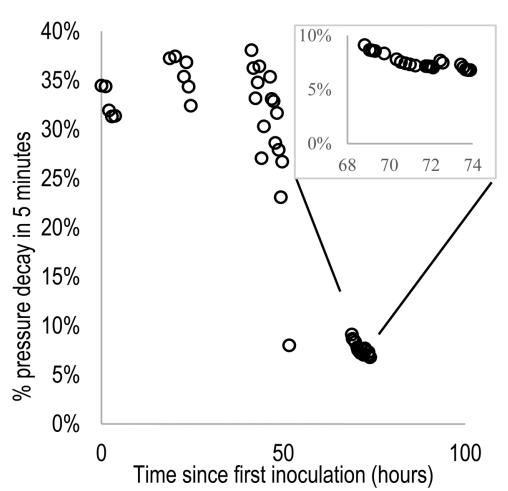

Figure 3. Pressure decay (in \%) over $5 \mathrm{~min}$ after well shut in. The pressure decay was observed to decrease from the beginning to the end of the experiment.

Fracture Extension Pressure. At the termination of the experiment, the formation was refractured to assess the postexperiment fracturing pressure. The fracture extension pressure measured downhole was $111.6 \mathrm{~atm}$ compared to 96.6 atm pre-experiment (Figure S3). This strongly suggests that the MICP treatment increased the formation's resistance to refracturing, which agrees with observations from laboratory studies. ${ }^{15,19}$ The increase of fracture extension pressure indicated that the pressure required to flow fluid through the fracture and the pressure required to create new fracture volume had increased because of biomineralization treatment. ${ }^{31}$ 
Despite the positive correlation to previous laboratory studies, in the field test it cannot be determined whether (i) the original fracture reopened, (ii) the formation fractured in a new location, or (iii) how far into the formation the new fracture propagated. In addition, a downhole pressure of $109.3 \mathrm{~atm}$ at $12.5 \mathrm{~L} / \mathrm{min}$ was necessary to inject brine after biomineralization treatment and refracturing, compared to $95.9 \mathrm{~atm}$ at the same flow rate before treatment, suggesting reduced injectivity into the formation.

Microbial Analysis. The injected organism (S. pasteurii) was not cultured or detected in a $16 \mathrm{~S}$ rRNA based community survey from the sample (Sample \#1) collected prior to the experiment. S. pasteurii was isolated on $\mathrm{BHI}+$ urea agar plates (Figure S1, Table S6) in the sample collected from the third day and the community profile analysis confirmed the presence of Sporosarcina spp. (Figure S2). Before inoculation, the predominant bacteria in the mixing zone sample were Pseudomonas spp. and other Bacillus spp. that were also detected through the culturing and isolation efforts (Table S6). The importance of these observations was that $S$. pasteurii was successfully cultured in large volume carboys in the field, injected into the subsurface with conventional oil field bailer delivery technologies, and detected as the most abundant species in the mixing zone sample on the third day. One potential difficulty not faced in this study was an elevated subsurface temperature (the temperature of fluids downhole was $24.5{ }^{\circ} \mathrm{C}$ ), which could be encountered in various potential applications of the MICP sealing technology. A limit to the ureolysis-induced MICP process is dictated by the microbial urease activity, which in the case of certain microorganisms can diminish with increasing temperature. ${ }^{32}$

Postexperiment Analysis: Sidewall Core. The side wall core collected approximately $1.8 \mathrm{~m}$ above the fracture sealing experimental depth $(340.8 \mathrm{~m}$ bgs $)$ was a representative piece of the casing and about $2.5 \mathrm{~cm}$ of the cement behind the casing. No formation material was retrieved from beyond the cement. The X-ray CT results show the presence of a channel through the cement material. In addition, autofluorescent mineral (autofluorescence is a property of calcite) ${ }^{33}$ was detected in the channel observed in the sidewall cement core (Figure 4). $\mathrm{XRD}$ results indicated the presence of calcite (data not shown) in the soft mud materials retrieved from behind the casing. This suggests that even 1 year after the demonstration, calcite was detected in an apparent flow channel present in the cement behind the casing pointing to the longevity of the mineral under these subsurface conditions. This also implies that biominerals might have formed not only in the fracture but also in a flow channel in the cement $1.8 \mathrm{~m}$ above the fracture zone. Although the presence of these materials before the experiment cannot be ruled out, this might be an additional indication that the microbially induced precipitation of calcium carbonate occurred in the wellbore environment and that calcite can be stable in this environment.

MICP as an Emerging Technology. In this study, methods were developed to promote MICP in the subsurface with conventional oil field delivery technology. In the field, there are a number of challenges that must be overcome that might not be encountered in the laboratory. Examples of the challenges faced here included: (1) limited sampling capability, (2) possible reaction of the reagents in the wellbore rather than in the formation, (3) the possibility of microorganism already present in the sandstone formation that might compete for the injected substrates, and (4) the possibility of drilling mud near
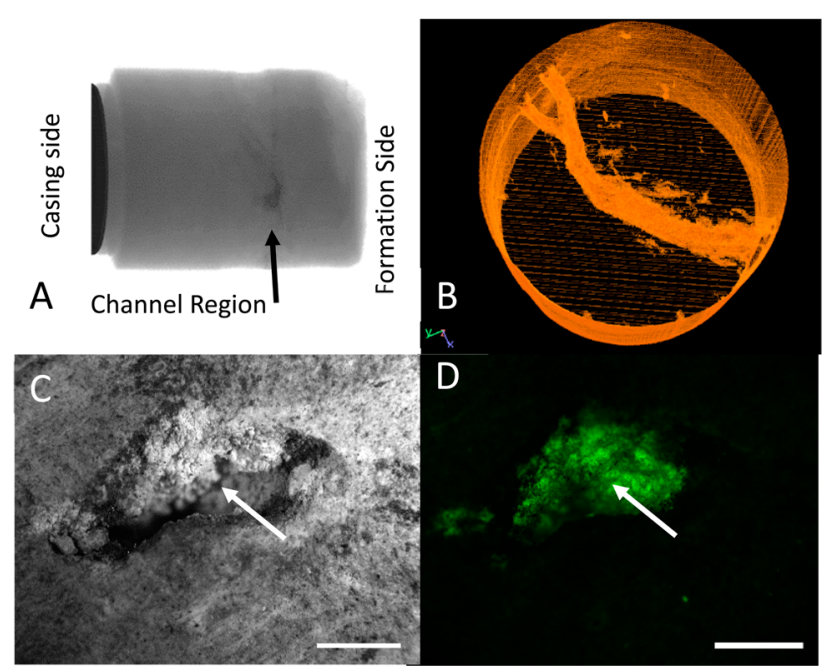

Figure 4. X-ray $\mathrm{CT}$, reflected light and fluorescent stereomicroscopy images of the cement retrieved during side wall coring. (A, B). A channel was detected in the $2.5 \mathrm{~cm}$ diameter, $2.5 \mathrm{~cm}$ long cement core as evidenced by the CT scan. (C, D). The region of the channel was imaged with reflected light (C) and fluorescence (D). The scale bar for the stereoscope images is $2 \mathrm{~mm}$. Autofluorescent mineral was detected in the flow channel (arrows).

the casing formation interface that might have contained biocide. These challenges appeared to be overcome by the developed MICP treatment strategy which resulted in a significant impact on key formation properties: (1) injectivity decreased significantly compared to pre-treatment levels and (2) the pressure required to refracture and extend the fracture both increased after treatment. The MICP treatment also resulted in a reduction in pressure decay after the pumping ceased (well shut in), a measure of improved mechanical integrity. Unfortunately, because of the limited ability to observe directly the process, some uncertainty remains regarding how far into the formation cells were injected and where or whether biomineralization took place.

Although not discussed in this paper, a reactive transport model developed by us ${ }^{21,34-36}$ was used to simulate the injection strategy that predicted a 1 order of magnitude permeability reduction and a maximum calcite volume fraction at approximately $1 \mathrm{~m}$ in the radial direction from the injection point. Although impossible to verify this downhole, the reduction in injectivity and pressure decay, positive reactive transport model predictions, the observation of calcite in materials (cement core channel and mud from behind the casing) give some confidence that MICP treatment successfully sealed the fracture.

Additional investigations and large scale demonstrations are required to develop further this technology for routine applications. Demonstrating the ability to seal leakage pathways between wellbore cement/steel or cement/formation interfaces as well as the potential of the MICP sealing technology to mitigate gas leakage is important in advancing the technology as a wellbore integrity remediation method. Another significant route of inquiry toward the application of mineral precipitation sealing technologies in the subsurface is developing methods to expand the subsurface application to greater depths and thus temperatures through the potential use of thermophilic microbes or enzymatic treatment strategies. 


\section{ASSOCIATED CONTENT}

\section{S Supporting Information}

The Supporting Information is available free of charge on the ACS Publications website at DOI: 10.1021/acs.est.5b05559.

Subsurface sample chemical analysis, field injection methods and sequences, chemical analysis, microbial isolate and community analysis methods, and additional details about the postexperiment analysis (PDF).

\section{AUTHOR INFORMATION}

\section{Corresponding Author}

*Adrienne Phillips. E-mail: adrienne.phillips@biofilm.montana. edu. Phone: 406.994.2119.

\section{Author Contributions}

The paper was written through contributions of all authors. All authors have given approval to the final version of the paper. All authors contributed equally.

\section{Funding}

This research was sponsored by two U.S. Department of Energy (DOE) programs: DE-FE0004478, “Advanced $\mathrm{CO}_{2}$ Leakage Mitigation using Engineered Biomineralization Sealing Technologies" and DE-FE000959, "Field Test and Evaluation of Engineered Biomineralization Technology for Sealing Existing Wells" with matching support from Southern Company Generation and Shell International Exploration and Production B.V. Additional financial support was also provided by DOE DE-FG02-13ER86571 and NSF Award No. DMS0934696.

Notes

The authors declare no competing financial interest.

${ }^{\nabla}$ Formerly with Schlumberger Carbon Services.

\section{ACKNOWLEDGMENTS}

Any opinions, findings, conclusions, or recommendations expressed herein are those of the authors and do not necessarily reflect the views of the Department of Energy (DOE). Support for the Environmental and Biofilm Mass Spectrometry Facility through DURIP, Contract Number: W911NF0510255 and the MSU Thermal Biology Institute from the NASA Exobiology Program Project NAG5-8807 is acknowledged. The imaging work was made possible by microscope facilities at the Center for Biofilm Engineering and the MSU SubZero Science and Engineering Research Facilities, which were supported by funding obtained from the NSF-MRI Program and the M.J. Murdock Charitable Trust. Special thanks to Betsey Pitts for assistance with the imaging and Olivia Firth for the CT scanning. Support from undergraduate engineering researchers was extremely important to this research and thanks is extended to Eric Troyer, Oliva Firth, and Adam Rothman. Special acknowledgment is extended to Richard Esposito and John Poole of Southern Company and Jim Kirksey and Billy Hancock of Schlumberger Carbon Services for the effort to create a successful field experiment. Thanks are also extended to the anonymous reviewers whose comments greatly improved the paper.

\section{REFERENCES}

(1) Gasda, S. E.; Bachu, S.; Celia, M. A. Spatial characterization of the location of potentially leaky wells penetrating a deep saline aquifer in a mature sedimentary basin. Environ. Geol. 2004, 46 (6-7), 707-720.
(2) Kang, M.; Kanno, C. M.; Reid, M. C.; Zhang, X.; Mauzerall, D. L.; Celia, M. A.; Chen, Y.; Onstott, T. C. Direct measurements of methane emissions from abandoned oil and gas wells in Pennsylvania. Proc. Natl. Acad. Sci. U. S. A. 2014, 111 (51), 18173-18177.

(3) Carey, W. J.; Svec, R.; Grigg, R.; Zhang, J.; Crow, W. Experimental investigation of wellbore integrity and $\mathrm{CO}_{2}$-brine flow along the casing-cement microannulus. Int. J. Greenhouse Gas Control 2010, 4 (2), 272-282.

(4) Shukla, R; Ranjith, P.; Haque, A.; Choi, X. A review of studies on $\mathrm{CO}_{2}$ sequestration and caprock integrity. Fuel 2010, 89 (10), 26512664.

(5) West, J. J.; Fiore, A. M. Management of tropospheric ozone by reducing methane emissions. Environ. Sci. Technol. 2005, 39 (13), 4685-4691.

(6) Phillips, A.; Gerlach, R.; Lauchnor, E.; Mitchell, A.; Cunningham, A.; Spangler, L. Engineered applications of ureolytic biomineralization: a review. Biofouling 2013, 29 (6), 715-733.

(7) Hammes, F.; Verstraete, W. Key roles of $\mathrm{pH}$ and calcium metabolism in microbial carbonate precipitation. Rev. Environ. Sci. Bio/ Technol. 2002, 1, 3-7.

(8) Mitchell, A.; Dideriksen, K.; Spangler, L.; Cunningham, A.; Gerlach, R. Microbially enhanced carbon capture and storage by mineral-trapping and solubility-trapping. Environ. Sci. Technol. 2010, 44, 5270-5276.

(9) De Muynck, W.; De Belie, N.; Verstraete, W. Microbial carbonate precipitation in construction materials: A review. Ecol. Eng. 2010, 36 (2), 118-136.

(10) Wang, J. Y.; De Belie, N.; Verstraete, W. Diatomaceous earth as a protective vehicle for bacteria applied for self-healing concrete. J. Ind. Microbiol. Biotechnol. 2012, 39 (4), 567-577.

(11) van Paassen, L.; Ghose, R.; van der Linden, T.; van der Star, W.; van Loosdrecht, M. Quantifying biomediated ground improvement by ureolysis: large-scale biogrout experiment. J. Geotech. Geoenviron. Eng. 2010, 136 (12), 1721-1728.

(12) DeJong, J. T.; Mortensen, B. M.; Martinez, B. C.; Nelson, D. C. Bio-mediated soil improvement. Ecol. Eng. 2010, 36 (2), 197-210.

(13) Tobler, D.; Maclachlan, E.; Phoenix, V. Microbially mediated plugging of porous media and the impact of differing injection strategies. Ecol. Eng. 2012, 42, 270-278.

(14) Fujita, Y.; Taylor, J.; Gresham, T.; Delwiche, M.; Colwell, F.; McLing, T.; Petzke, L.; Smith, R. Stimulation of microbial urea hydrolysis in groundwater to enhance calcite precipitation. Environ. Sci. Technol. 2008, 42, 3025-3032.

(15) Phillips, A. J.; Lauchnor, E.; Eldring, J.; Esposito, R.; Mitchell, A. C.; Gerlach, R.; Cunningham, A. B.; Spangler, L. H. Potential $\mathrm{CO}_{2}$ leakage reduction through biofilm-induced calcium carbonate precipitation. Environ. Sci. Technol. 2013, 47 (1), 142-149.

(16) Dupraz, S.; Menez, B.; Gouze, P.; Leprovost, R.; Benezeth, P.; Pokrovsky, O.; Guyot, F. Experimental approach of $\mathrm{CO}_{2}$ biomineralization in deep saline aquifers. Chem. Geol. 2009, 265, 54-62.

(17) Cunningham, A. B.; Phillips, A. J.; Troyer, E.; Lauchnor, E.; Hiebert, R.; Gerlach, R; Spangler, L. Wellbore leakage mitigation using engineered biomineralization. Energy Procedia 2014, 63, 46124619.

(18) Cuthbert, M. O.; McMillan, L. A.; Handley-Sidhu, S.; Riley, M. S.; Tobler, D. J.; Phoenix, V. R. A field and modeling study of fractured rock permeability reduction using microbially induced calcite precipitation. Environ. Sci. Technol. 2013, 47 (23), 13637-13643.

(19) Phillips, A. J.; Eldring, J.; Hiebert, R.; Lauchnor, E.; Mitchell, A. C.; Cunningham, A.; Spangler, L.; Gerlach, R. Design of a meso-scale high pressure vessel for the laboratory examination of biogeochemical subsurface processes. J. Pet. Sci. Eng. 2015, 126, 55-62.

(20) Burbank, M. B.; Weaver, T. J.; Green, T. L.; Williams, B. C.; Crawford, R. L. Precipitation of calcite by indigenous microorganisms to strengthen liquefiable soils. Geomicrobiol. J. 2011, 28 (4), 301-312.

(21) Ebigbo, A.; Phillips, A.; Gerlach, R.; Helmig, R.; Cunningham, A. B.; Class, H.; Spangler, L. H. Darcy-scale modeling of microbially induced carbonate mineral precipitation in sand columns. Water Resour. Res. 2012, 48 (7), W07519. 
(22) Yoon, J. H.; Lee, K. C.; Weiss, N.; Kho, Y. H.; Kang, K. H.; Park, Y. H. Sporosarcina aquimarina sp. nov., a bacterium isolated from seawater in Korea, and transfer of Bacillus globisporus (Larkin and Stokes 1967), Bacillus psychrophilus (Nakamura 1984) and Bacillus pasteurii (Chester 1898) to the genus Sporosarcina as Sporosarcina globispora comb. nov., Sporosarcina psychrophila comb. nov. and Sporosarcina pasteurii comb. nov., and emended description of the genus Sporosarcina. I. Int. J. Syst. Evol. Microbiol. 2001, 51 (3), 10791086.

(23) Herigstad, B.; Hamilton, M.; Heersink, J. How to optimize the drop plate method for enumerating bacteria. J. Microbiol. Methods 2001, 44 (2), 121-129.

(24) Jung, D.; Biggs, H.; Erikson, J.; Ledyard, P. New colorimetric reaction for end-point, continuous-flow, and kinetic measurement of urea. Clin. Chem. 1975, 21 (8), 1136-1140.

(25) Phillips, A. Biofilm-Induced Calcium Carbonate Precipitation: Application in the Subsurface. Ph.D. Dissertation, Montana State University, Bozeman, MT, 2013.

(26) Wheeler, L. A. Establishment of ureolytic biofilms and their influence on the permeability of pulse-flow porous media column systems. Master's Thesis, Montana State University, Bozeman, MT, 2009.

(27) Mitchell, A. C.; Phillips, A. J.; Kaszuba, J. P.; Hollis, W. K.; Cunningham, A. L. B.; Gerlach, R. Microbially enhanced carbonate mineralization and the geologic containment of $\mathrm{CO}_{2}$. Geoch. et Cosm. Acta 2008, 72 (12), A636-A636.

(28) Lauchnor, E. G.; Schultz, L. N.; Bugni, S.; Mitchell, A. C.; Cunningham, A. B.; Gerlach, R. Bacterially induced calcium carbonate precipitation and strontium coprecipitation in a porous media flow system. Environ. Sci. Technol. 2013, 47 (3), 1557-1564.

(29) 40 CFR Part 146 - Underground Injection Control Program: Criteria and Standards.

(30) Koplos, J.; Kobelski, B.; Karimjee, A.; Sham, C. UIC Program Mechanical Integrity Testing: Lessons for Carbon Capture and Storage? In Fifth Annual Conference on Carbon Capture and Sequestration, May 8-11, 2006, Alexandria, VA, 2006.

(31) Fjar, E.; Holt, R. M.; Raaen, A.; Risnes, R.; Horsrud, P. Petroleum Related Rock Mechanics, 2nd ed.; Elsevier: Amsterdam, The Netherlands, 2008.

(32) Dhami, N.; Reddy, M. S.; Mukherjee, A. Synergistic role of bacterial urease and carbonic anhydrase in carbonate mineralization. Appl. Biochem. Biotechnol. 2014, 172 (5), 2552-2561.

(33) Yoshida, N.; Higashimura, E.; Saeki, Y. Catalytic biomineralization of fluorescent calcite by the thermophilic bacterium Geobacillus thermoglucosidasius. Appl. Environ. Microbiol. 2010, 76 (21), 73227327.

(34) Hommel, J.; Cunningham, A. B.; Helmig, R.; Ebigbo, A.; Class, $\mathrm{H}$. Numerical Investigation of mcrobially induced calcite precipitation as a leakage mitigation technology. Energy Procedia 2013, 40, 392397.

(35) Hommel, J.; Lauchnor, E.; Phillips, A.; Gerlach, R.; Cunningham, A. B.; Helmig, R.; Ebigbo, A.; Class, H. A revised model for microbially induced calcite precipitation: Improvements and new insights based on recent experiments. Water Resour. Res. 2015, 51 (5), 3695-3715.

(36) Hommel, J.; Lauchnor, E.; Gerlach, R.; Cunningham, A. B.; Ebigbo, A.; Helmig, R.; Class, H. Investigating the influence of the initial biomass distribution and injection strategies on biofilmmediated calcite precipitation in porous media. Transp. Porous Media 2015, 1-23. 